\title{
Inhibitory Effect of Erythraline on Toll-Like Receptor Signaling Pathway in RAW264.7 Cells
}

\author{
Tadahiro Etoh, ${ }^{a}$ Yong Pil Kim, ${ }^{* a}$ Ayumi Ohsaki, ${ }^{b}$ Kanki Komiyama, ${ }^{c}$ and Masahiko Hayashi ${ }^{a}$ \\ ${ }^{a}$ Faculty of Pharmacy, Iwaki Meisei University; 5-5-1 Iino, Chuo-dai, Iwaki, Fukushima 970-8551, Japan: \\ ${ }^{b}$ Institute of Biomaterials and Bioengineering, Tokyo Medical and Dental University; 2-3-10 Surugadai, Kanda, \\ Chiyoda-ku, Tokyo 101-0062, Japan: and ${ }^{c}$ Kitasato Research Center of Environmental Science, Kitasato University; \\ 1-15-1 Kitasato, Sagamihara, Kanagawa 228-0829, Japan. \\ Received October 18, 2012; accepted June 3, 2013
}

Erythraline, isolated from the bark of Erythrina crista-galli which are used as Brazilian medicine plant for the treatment of inflammation diseases, suppressed nitric oxide (NO) production and induction of inducible nitric oxide synthase (iNOS) expression in RAW264.7 cells stimulated by lipopolysaccharide (LPS). Because of Toll-like receptor (TLR) 4 and its signal transduction are indispensable to the production of NO and iNOS expression by LPS, we investigated the effects of erythraline on TLR signaling molecules. Western blot analysis revealed that the degradation of inhibitor of nuclear factor (NF)- $\kappa$ B (I $\kappa$ B) by LPS was suppressed by erythraline. Moreover, erythraline inhibited not only LPS-induced phosphorylation of I $\mathrm{B}$ kinase (Ikk) but also phosphorylation of mitogen-activated protein kinases (MAPKs). However, it showed no effect on LPS -induced phosphorylation of transforming growth factor (TGF)- $\beta$-activated kinase (TAK) 1 that exists upstream of Ikk and MAPKs, and is required for the activation of these signaling molecules on TLR signaling pathway. These results suggested that erythraline might have inhibited the kinase activity of TAK1. Furthermore, these results were supported from the inhibitory pattern of erythraline on TLR signaling molecules when the cells were stimulated by TLR2 ligand, peptidoglycan which activates the same pathway as LPS on TLR signal transduction.

Key words erythraline; transforming growth factor- $\beta$ activated kinase 1; anti-inflammation; toll-like receptor

The Erythrina genus (Leguminosae) includes more than 100 species and is distributed in South America and tropical and subtropical regions of South Asia. Erythrina crista-galli L. is commonly known as the cockspur coral tree. It is also called "Corticeira" in Brazil and its bark is used for the treatment of rheumatism, hepatitis, sedation, and hypnogenesis. ${ }^{1)}$ In the course of a screening program for natural compounds showing nitric oxide (NO) inhibition activity, we found that erythraline which is Erythrinan alkaloids isolated from Erythrina crista-galli inhibited lipopolysaccharide (LPS)-induced NO production. ${ }^{2}$ NO is known to be an endogenous regulator of cell and tissue function and important pro-inflammatory mediator in the inflammatory process. ${ }^{3)} \mathrm{NO}$ is a free radical synthesized from L-arginine by 3 isoforms of NO synthase (NOS) such as endothelial NOS (eNOS), neuronal NOS (nNOS), and inducible NOS (iNOS). ${ }^{4)}$ iNOS is particularly related to the inflammatory response and expressed in response to LPS, interferon- $\gamma$, and various pro-inflammatory cytokines such as tumor necrosis factor (TNF)- $\alpha$ and interleukin (IL)-1. ${ }^{5}$ ) In addition, iNOS is expressed in various cells including macrophages, neutrophils, epithelial cells, and hepatocytes. NO which is produced by iNOS acts in antimicrobial and antiviral processes. However, excessive production of NO leads to several autoimmune and chronic inflammatory diseases. ${ }^{6}$ )

Toll-like receptor (TLR) 4 is indispensable for the production of NO in response to LPS. TLRs are key components of innate immunity and induce innate immune responses by recognizing invading microbial pathogens. ${ }^{7)}$ The innate immunity is the first step in biophylaxis and other defenses against bacterial or viral infections, which occur through a multitude of inflammatory responses. However, an excessive immune re-

The authors declare no conflict of interest. sponse might be connected with inflammatory disorders such as sepsis and chronic inflammation. ${ }^{8)}$ Thirteen TLRs have been discovered in mammalian cells and have been identified to have different ligands. ${ }^{9)}$ It is described in previous studies that TLR2 recognizes zymosan and peptidoglycan, ${ }^{10)}$ TLR4 recognizes lipopolysaccharide, ${ }^{11)}$ TLR5 recognizes flagellin, ${ }^{12)}$ and TLR7/8 recognizes single stranded RNA. ${ }^{13,14)}$ It has been reported that TLRs relate to many intracellular signaling molecules, such as myeloid differentiation factor (MyD) 88, interleukin-1 receptor associated kinase (IRAK)-1, IRAK-4, TIR domain-containing adapter protein (TIRAP), TNF receptor associated factor (TRAF) 6, transforming growth factor (TGF)- $\beta$ activated kinase (TAK) 1 , inhibitor of nuclear factor (NF) $-\kappa \mathrm{B}(\mathrm{I} \kappa \mathrm{B}), \mathrm{I} \kappa \mathrm{B}$ kinase (Ikk), and p38, p44/42 mitogen-activated protein kinase (MAPK). ${ }^{15,16)}$ The stimulation of TLRs is required for the activation of the downstream signaling pathways leading to the activation and nuclear translocation of NF- $\kappa \mathrm{B}$. The activation and translocation of NF- $\kappa \mathrm{B}$ leads to the expression of its target genes, and induces the production of various inflammatory mediators such as NO, prostaglandin (PG) $\mathrm{E}_{2}$, and TNF- $\alpha$.

In the present study, we investigated the effect of erythraline on LPS- and peptidoglycan (PGN)-induced TLR signal transduction. The aim of this study was to analyze the mechanism of action for the inhibitory effect of erythraline on LPSinduced NO production and to clarify the molecular target of erythraline within TLR signaling pathways.

\section{MATERIALS AND METHODS}

Plant Materials and Isolation of Erythraline Purchase and identification of the bark of Erythrina crista-galli and isolation of erythraline were described previously. ${ }^{2)}$ 
Reagents The polyclonal antibodies specific for $\mathrm{I} \kappa \mathrm{B}-\alpha$, Ikk $\alpha$, phospho-Ikk $\alpha / \beta$, p38 MAP kinase, phospho-p38 MAP kinase, SAPK c-Jun N-terminal kinase (JNK), phosphoSAPK/JNK, TAK1, IRAK-1 and anti-rabbit immunoglobulin $\mathrm{G}$ (IgG), horseradish peroxidase (HRP)-linked antibody were purchased from Cell Signaling Technology (Danvers, MA, U.S.A.). The polyclonal antibodies specific for cyclooxygenase (COX)-1 and NOS2, were purchased from Santa Cruz Biotechnology (Delaware, CA, U.S.A.). Biotinylated anti-rabbit, mouse, goat $\operatorname{IgG}(\mathrm{H}+\mathrm{L})$ and Vectastain ABC kit were purchased form Vector Laboratories (Burlimgame, CA, U.S.A.). The ECL Western blot detection reagent was purchased from GE Healthcare (Piscataway, NJ, U.S.A.). Lipopolysaccharides (LPS, from Escherichia coli, serotype 026:B6), peptidoglycans (PGN, from Staphylococcus aureus), and protease inhibitor cocktail were obtained from Sigma-Aldrich (St. Louis, MO, U.S.A.).

Cell Culture RAW264.7 cells, a murine macrophage cell line, were obtained from Riken Cell Bank (Tsukuba, Ibaraki, Japan). Cells were cultured in Dulbecco's modified Eagle's medium (DMEM), phenol red-free, supplemented with $10 \%$ fetal bovine serum (FBS; EIDIA, Tokyo, Japan), $100 \mathrm{U} / \mathrm{mL}$ penicillin (Meiji Seika, Tokyo, Japan) and $100 \mathrm{mg} / \mathrm{mL}$ streptomycin (Meiji Seika). In all experiments, the cells were grown to $80-90 \%$ confluence and subjected to no more than 15 cell passages.

Measurement of Cell Viability Cell viability was assessed using the 3-(4,5-dimethylthiazol-2-yl)-2,5-diphenyltetrazolium bromide (MTT) assay. RAW264.7 cells $\left(1 \times 10^{5}\right.$ cells/well) were pre-incubated at $37^{\circ} \mathrm{C}$ for $3 \mathrm{~h}$ with or without various concentrations of erythraline $(3,10$, and $30 \mu \mathrm{M})$. After pre-incubation, LPS $(10 \mu \mathrm{g} / \mathrm{mL})$ was added and cells were incubated for $20 \mathrm{~h}$. After incubation MTT (5 mg/mL; Sigma) was then added, and the cells were incubated for $4 \mathrm{~h}$. The culture medium was removed and the cells were dissolved in dimethyl sulfoxide (Wako Pure Chemical Industries, Ltd., Osaka, Japan). The optical densities (OD) at 540 and $620 \mathrm{~nm}$ were measured using a microplate reader (Model 680, BioRad Laboratories, CA, U.S.A.).

Measurement of NO The NO concentrations in the conditioned medium were determined by using Griess reagent $[1 \%$ sulfanilamide (Sigma), $0.1 \% \quad N$-1-naphthylenediamine dihydrochloride (Sigma), and $2.5 \%$ phosphoric acid (Kanto Chemicals, Tokyo, Japan)]. ${ }^{17)}$ RAW264.7 cells $\left(1 \times 10^{5}\right.$ cells/ well) were pre-incubated at $37^{\circ} \mathrm{C}$ for $3 \mathrm{~h}$ with or without various concentrations of erythraline $(3,10$, and $30 \mu \mathrm{M})$. After pre-incubation, LPS or PGN $(10 \mu \mathrm{g} / \mathrm{mL})$ was added and cells were incubated for $20 \mathrm{~h}$. After incubation, $100 \mu \mathrm{L}$ aliquots of medium were mixed with an equal volume of Griess reagent. The absorbance was measured at $540 \mathrm{~nm}$ with a microplate reader after incubation for $5 \mathrm{~min}$.

Western Blot Analysis RAW264.7 cells $\left(2 \times 10^{6}\right.$ cells $)$ in 6 well tissue culture dishes were plated. The cells were preincubated at $37^{\circ} \mathrm{C}$ for $3 \mathrm{~h}$ with or without various concentrations of erythraline and treated with LPS (iNOS, COX-2: 16h, TAK1: $5 \mathrm{~min}$, IRAK-1, Ikk- $\alpha, \mathrm{I} \kappa \mathrm{B}-\alpha, \mathrm{JNK}$ and p38 MAPK: $10 \mathrm{~min}$ ) or PGN (TAK1: $10 \mathrm{~min}$, IRAK-1 and Ikk- $\alpha$ : $20 \mathrm{~min}$, $\mathrm{I} \kappa \mathrm{B}-\alpha$ : $30 \mathrm{~min})$. The cells were washed in cold phosphatebuffered saline (PBS), and $50 \mu \mathrm{L}$ of lysis buffer (20 mm $N-(2-$ hydroxyethyl)piperazine- $N^{\prime}$-2-ethanesulfonic acid (HEPES) $\mathrm{pH}$ 7.3, $1 \%$ Triton-X, $10 \%$ glycerol, $1 \mathrm{~mm}$ sodium fluoride, $1 \mathrm{~mm}$
$\mathrm{Na}_{3} \mathrm{VO}_{4}$, and $10 \%$ protease inhibitor cocktail) was added to each well. After $15 \mathrm{~min}$ incubation on ice, the cells were collected into sample tubes by silicon policeman and incubated for $10 \mathrm{~min}$ on ice. The cells were then centrifuged at $15490 \times \boldsymbol{g}$ for $20 \mathrm{~min}$ at $4^{\circ} \mathrm{C}$. The supernatant fractions were boiled for $5 \mathrm{~min}$ in sample buffer [ $50 \mathrm{~mm}$ Tris, $\mathrm{pH} 7.4,4 \%$ sodium dodecyl sulfate (SDS), 10\% glycerol, 4\% 2-mercaptoethanol, and $0.05 \mathrm{mg} / \mathrm{mL}$ bromophenol blue], and stored at $-80^{\circ} \mathrm{C}$. Preparation of nuclear extracts was performed, as follows. RAW264.7 cells $\left(2 \times 10^{7}\right.$ cells $/$ well $)$ were plated in $10 \mathrm{~cm}$ tissue culture dishes. The cells were pre-incubated at $37^{\circ} \mathrm{C}$ for $3 \mathrm{~h}$ with or without various concentrations of erythraline and treated with LPS for $15 \mathrm{~min}$. At the end of incubation, the cells were harvested by scraping, followed by centrifugation at $1500 \mathrm{rpm}$ and $4^{\circ} \mathrm{C}$ for $5 \mathrm{~min}$. After centrifugation, the cell pellet was resuspended in $800 \mu \mathrm{L}$ of Tris-buffered $\mathrm{KCl}$ solution (20 mм Tris- $\mathrm{HCl}, \mathrm{pH} 7.8,50 \mathrm{~mm} \mathrm{KCl}$ ) supplemented with $1 \mathrm{~mm}$ dithiothreitol, $50 \mathrm{~mm}$ sodium fluoride, $1 \mathrm{~mm} \mathrm{Na} \mathrm{VO}_{4}$ and protease inhibitor cocktail. Nonidet P-40 substitute (Wako) was added at $0.6 \%$ final concentration, and the cell suspension was vortexed for $10 \mathrm{~s}$ and centrifuged at $15490 \times \boldsymbol{g}$ for $1 \mathrm{~min}$ at $4^{\circ} \mathrm{C}$ to obtain the nuclei pellet. The nuclei were resuspended in $30 \mu \mathrm{L}$ ice-cold Tris-buffered high- $\mathrm{KCl}$ solution $(20 \mathrm{~mm}$ Tris- $\mathrm{HCl}$, pH 7.8, $500 \mathrm{~mm} \mathrm{KCl}$ ) supplemented with $20 \%$ glycerol, $1 \mathrm{~mm}$ dithiothreitol, $50 \mathrm{~mm}$ sodium fluoride, $1 \mathrm{~mm} \mathrm{Na} \mathrm{VO}_{4}$ and protease inhibitor cocktail. After $1 \mathrm{~h}$ incubation on ice, the nuclear lysate was centrifuged at $15490 \times \boldsymbol{g}$ for $20 \mathrm{~min}$ at $4^{\circ} \mathrm{C}$, and the supernatant (nuclear extract) was mixed with $3 \times$ sample buffer (50 mu Tris, pH 7.4, 4\% SDS, 10\% glycerol, 4\% 2-mercaptoethanol and $0.05 \mathrm{mg} / \mathrm{mL}$ bromophenol blue) at $2: 1$ ratio $(\mathrm{v} / \mathrm{v})$, boiled for $5 \mathrm{~min}$, and stored at $-80^{\circ} \mathrm{C}$. The proteins were separated by $8 \%$ SDS-polyacrylamide gel electrophoresis (PAGE) and transferred to a polyvinylidene difluoride (PVDF) membrane in transfer buffer $(20 \mathrm{~mm}$ Tris, $\mathrm{pH} 8.3$, $150 \mathrm{~mm}$ glycine, and $20 \% \mathrm{MeOH}$ ). The PVDF membrane was then blocked by incubation in 20\% Block Ace (DS Pharma Biomedical, Osaka, Japan). Subsequently, the membrane was incubated with the antibody for overnight at $4^{\circ} \mathrm{C}$. After incubation, the membrane was washed and incubated for $4 \mathrm{~h}$ at $4^{\circ} \mathrm{C}$ with a secondary antibody. Thereafter, the membrane was incubated for $30 \mathrm{~min}$ at room temperature with $\mathrm{ABC}$ reagent. The protein bands were visualized using an enhanced chemiluminescence system.

Statistical Analysis The data were expressed as the mean \pm S.E.M. of the results obtained from a number of experiments. The statistical significance of the results was analyzed by Student's $t$-test.

\section{RESULTS}

Effects of Erythraline on Cell Viability To confirm that the inhibitory effect of erythraline on NO production was not because of cytotoxicity, we examined its effects on cell viability. RAW264.7 cells $\left(1 \times 10^{5}\right.$ cells/well) were pre-incubated at $37^{\circ} \mathrm{C}$ for $3 \mathrm{~h}$ with or without various concentrations of erythraline $(3,10$, and $30 \mu \mathrm{M})$ and LPS $(10 \mu \mathrm{g} / \mathrm{mL})$. In these conditions, the cytotoxicity of erythraline was evaluated with MTT assay, but cell viabilities were not affected (Fig. 1B).

Effects of Erythraline on LPS-Induced NO Production and iNOS Protein Induction When RAW264.7 cells were incubated at $37^{\circ} \mathrm{C}$ for $20 \mathrm{~h}$ in medium containing LPS $(10 \mu \mathrm{g} /$ 
A<smiles>CO[C@H]1C=CC2=CCN3CCc4cc5c(cc4[C@]21C3)OCO5</smiles>

B

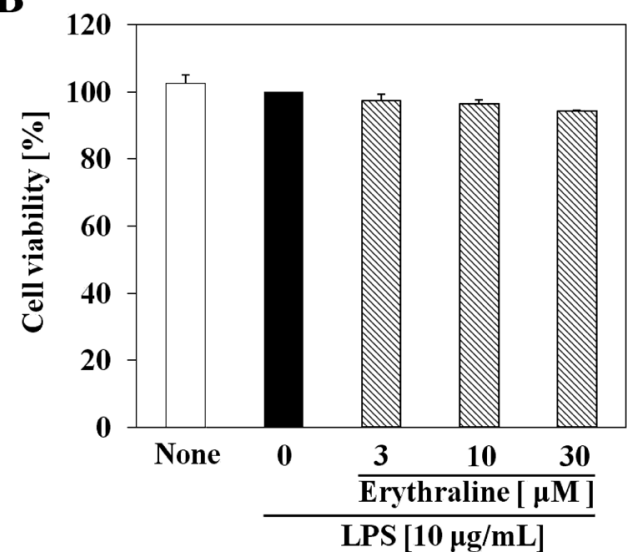

Fig. 1. The Chemical Structure of Erythraline (A) and Effects of Erythraline on Cell Viability in RAW264.7 Cells (B)

RAW264.7 cells $\left(1 \times 10^{5}\right.$ cells) were pre-treated at $37^{\circ} \mathrm{C}$ for $3 \mathrm{~h}$ with the indicated concentrations of erythraline before LPS $(10 \mu \mathrm{g} / \mathrm{mL})$ was added, and the cells were incubated for $20 \mathrm{~h}$. Cell viability was measured by MTT assay. LPS-treated control group is set to $100 \%$. The results shown are representatives of three independent experiments.

$\mathrm{mL}$ ), NO production was strongly increased (Fig. 2B). In the presence of erythraline ( $3 \mathrm{~h}$ pre-treatment), NO production stimulated by LPS was inhibited at $3-30 \mu \mathrm{M}$ in a concentration-dependent manner (Fig. 2B). western blot analysis revealed that iNOS levels at $16 \mathrm{~h}$ were increased by LPS. Under the condition, erythraline inhibited LPS-induced iNOS protein levels at $3-30 \mu \mathrm{M}$ in a concentration-dependent manner (Fig. 2A). In contrast, COX-1 protein levels which constitutively expressed in RAW264.7 cells did not change following treatment with LPS when determined at $16 \mathrm{~h}$ (Fig. 2A). Treatment with $3-30 \mu \mathrm{M}$ of erythraline in the presence of LPS also did not affect the protein levels of COX-1 at $16 \mathrm{~h}$ (Fig. 2A).

Effects of Erythraline on LPS-Induced NF-кB Nuclear Translocation Activation of $\mathrm{NF}-\kappa \mathrm{B}$ is known to be required for iNOS expression. Therefore, we investigated the translocation of $\mathrm{p} 65$, a subunit of NF- $\kappa \mathrm{B}$, from the cytosol to the nucleus by western blot analysis. RAW264.7 cells were pretreated for $3 \mathrm{~h}$ with $30 \mu \mathrm{M}$ of erythraline before LPS was added. Incubation of RAW264.7 cells at $37^{\circ} \mathrm{C}$ in medium containing LPS for $15 \mathrm{~min}$ increased p 65 protein levels in nuclear extracts, indicating that NF- $\kappa \mathrm{B}$ is translocated into nucleus on treatment with LPS (Fig. 3). In the presence of erythraline, the extent of translocation of NF- $\kappa \mathrm{B}$ into nucleus on treatment with LPS was suppressed. On the other hand, erythraline did not affect the protein levels of Oct-1, for maintaining normal physiological functions in nucleus (Fig. 3).

Effects of Erythraline on LPS-Induced TLR Signaling Transduction Factors To determine whether erythraline inhibited TLR signal transduction, cell lysates were prepared.
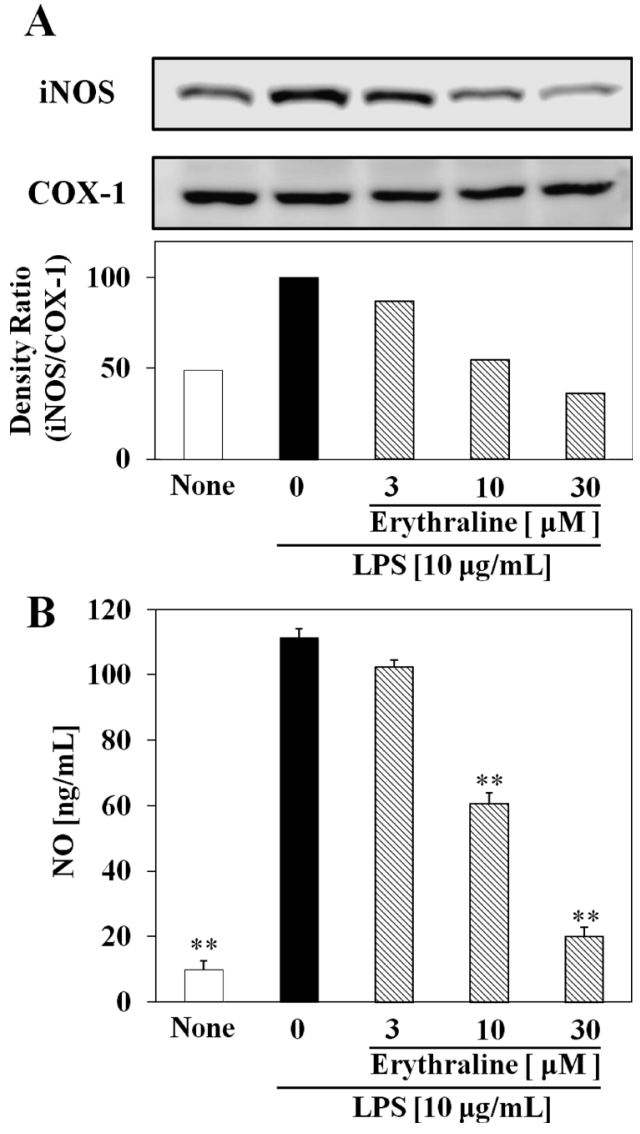

Fig. 2. Effects of Various Concentrations of Erythraline on NO Production and iNOS Expression in LPS-Stimulated RAW264.7 Cells

RAW264.7 cells $\left(2 \times 10^{6}\right.$ cells $)$ were pre-treated at $37^{\circ} \mathrm{C}$ for $3 \mathrm{~h}$ with the indicated concentrations of erythraline $(3-30 \mu \mathrm{M})$ before LPS $(10 \mu \mathrm{g} / \mathrm{mL})$ was added, and the cells were incubated for $16 \mathrm{~h}$. The protein levels of iNOS and COX-1 were determined by Western blot analysis (A). The relative density ratios of iNOS protein to COX-1 protein are shown as histograms. The density ratio of LPS control is set to 100. Results shown are representatives of three independent experiments. RAW264.7 cells $\left(1 \times 10^{5}\right.$ cells) were pre-treated at $37^{\circ} \mathrm{C}$ for $3 \mathrm{~h}$ with the indicated concentrations of erythraline before LPS $(10 \mu \mathrm{g} / \mathrm{mL})$ was added, and cells were incubated for $20 \mathrm{~h}$ (B). NO concentrations in medium were measured by Griess reaction. Results shown are representatives of three independent experiments. Statistical significance; $* * p<0.01$ vs. corresponding LPS control.

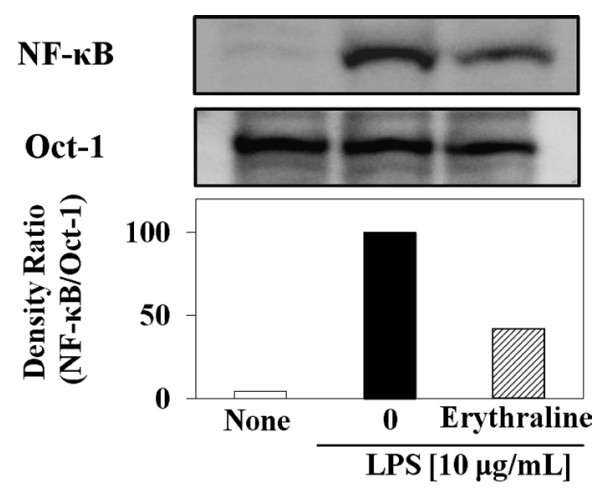

Fig. 3. Effects of Erythraline on LPS-Induced Nuclear Translocation of $\mathrm{NF}-\kappa \mathrm{B}(\mathrm{p} 65)$ in RAW264.7 Cells

RAW264.7 cells $\left(2 \times 10^{7}\right.$ cells $)$ were pre-treated at $37^{\circ} \mathrm{C}$ for $3 \mathrm{~h}$ with $30 \mu \mathrm{m}$ of erythraline before LPS $(10 \mu \mathrm{g} / \mathrm{mL})$ was added, and cells were incubated for $15 \mathrm{~min}$ (LPS). After incubation, protein levels of NF- $\kappa \mathrm{B}$ (p65) and Oct-1 in the nuclear extract samples were determined by Western blot analysis. The relative density ratios of NF- $\kappa$ B protein to Oct-1 protein are shown as histograms. The density ratio of LPS control is set to 100. Results shown are representatives of three independent experiments. 

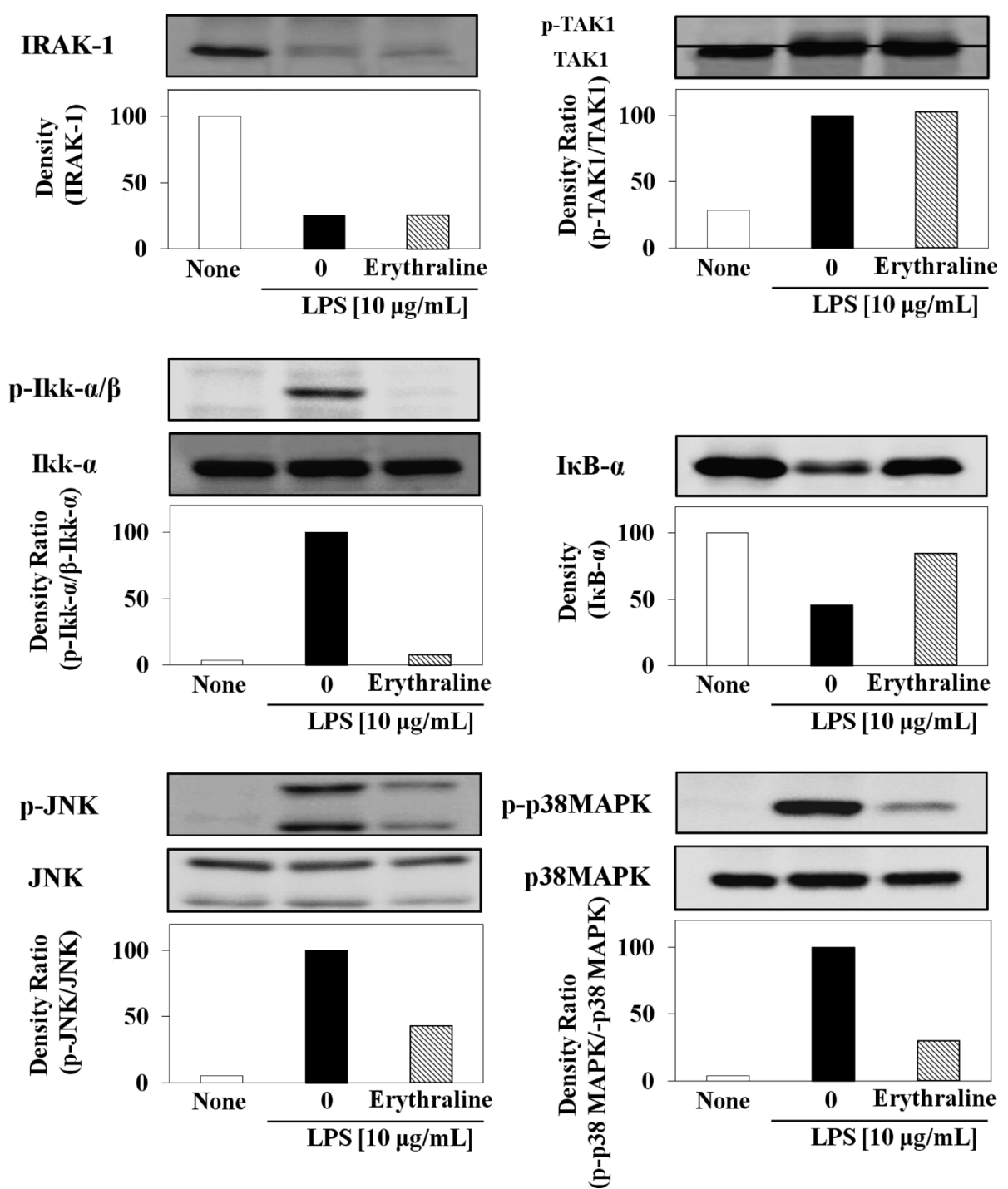

Fig. 4. Effects of Erythraline on LPS-Activated TLR Signaling Molecules and the Phosphorylation of MAPKs in RAW264.7 Cells

RAW264.7 cells $\left(2 \times 10^{6}\right.$ cells) were pre-treated at $37^{\circ} \mathrm{C}$ for $3 \mathrm{~h}$ with $30 \mu \mathrm{m}$ of erythraline before LPS $(10 \mu \mathrm{g} / \mathrm{mL})$ was added, and cells were incubated for indicated time. Incubation times were $5 \mathrm{~min}$ (TAK1) and $10 \mathrm{~min}$ (IRAK-1, Ikk- $\alpha, \mathrm{I} \kappa \mathrm{B}-\alpha, \mathrm{JNK}$ and $\mathrm{p} 38 \mathrm{MAPK}$ ). After incubation, each of the signal proteins and their phosphorylation or degradation forms were determined by Western blot analysis. The density of IRAK- 1 and I $\kappa$ B $-\alpha$ protein and the relative density ratios of phosphorylated each signal proteins (TAK1, Ikk- $\alpha$, JNK, and P38MAPK) to total each signal proteins are shown as histograms. The density ratio of LPS control is set to 100. Results shown are representatives of three independent experiments.

RAW264.7 cells were pre-treated with erythraline $(30 \mu \mathrm{M})$ for $3 \mathrm{~h}$ and then incubated in the presence or absence of LPS $(10 \mu \mathrm{g} / \mathrm{mL})$ for the different times (Fig. 4). When RAW264.7 cells were incubated at $37^{\circ} \mathrm{C}$ for each time in a medium containing LPS, TLR signal transduction factors, such as TAK1, Ikk, and MAPKs were strongly activated as phosphorylation and IRAK-1 and I $\kappa$ B- $\alpha$ degraded (Fig. 4). It has been reported that IRAK-1 is autophosphorylated and degraded after phosphorylation by IRAK-4. Under these conditions, erythraline at $30 \mu \mathrm{M}$ inhibited LPS-activated I $\kappa \mathrm{B}-\alpha$ degradation and Ikk- $\alpha / \beta$, p38 MAPK, and JNK phosphorylation. However, erythraline did not affect LPS-induced TAK-1 phosphorylation and IRAK-1 degradation (Fig. 4).

Effects of Erythraline on PGN-Induced NO Production and TLR Signaling Transduction Factors When RAW264.7 cells were incubated at $37^{\circ} \mathrm{C}$ for $20 \mathrm{~h}$ in medium containing PGN $(10 \mu \mathrm{g} / \mathrm{mL})$, NO production was strongly increased and erythraline ( $3 \mathrm{~h}$ pre-treatment) at 3-30 $\mu \mathrm{M}$ inhibited NO production stimulated by PGN in a concentration-de- pendent manner (Fig. 5B). Western blot analysis revealed that, when RAW264.7 cells were incubated at $37^{\circ} \mathrm{C}$ for the designated times in medium containing PGN, TLR signal transduction factors from IRAK- 1 to $\mathrm{I} \kappa \mathrm{B}-\alpha$ were strongly activated in term of phosphorylation or degradation (Fig. 5A). Under these conditions, erythraline at $30 \mu \mathrm{M}$ inhibited PGN-induced $\mathrm{I} \kappa \mathrm{B}-\alpha$ degradation and Ikk- $\alpha / \beta$ phosphorylation and did not affect PGN-activated TAK-1 phosphorylation and IRAK-1 degradation (Fig. 5A).

\section{DISCUSSION}

During our recent screening for an inhibitor of LPSinduced NO production in RAW264.7 cells, we isolated erythraline from Erythrina crista-galli. ${ }^{2)}$ In the present study, we pharmacologically analyzed its mechanism of action in TLR signaling pathways. Firstly, we should mention that erythraline at various concentrations $(3,10$, and $30 \mu \mathrm{M})$ did not affect cell viability of RAW264.7 cells following the $20 \mathrm{~h}$ incubation 

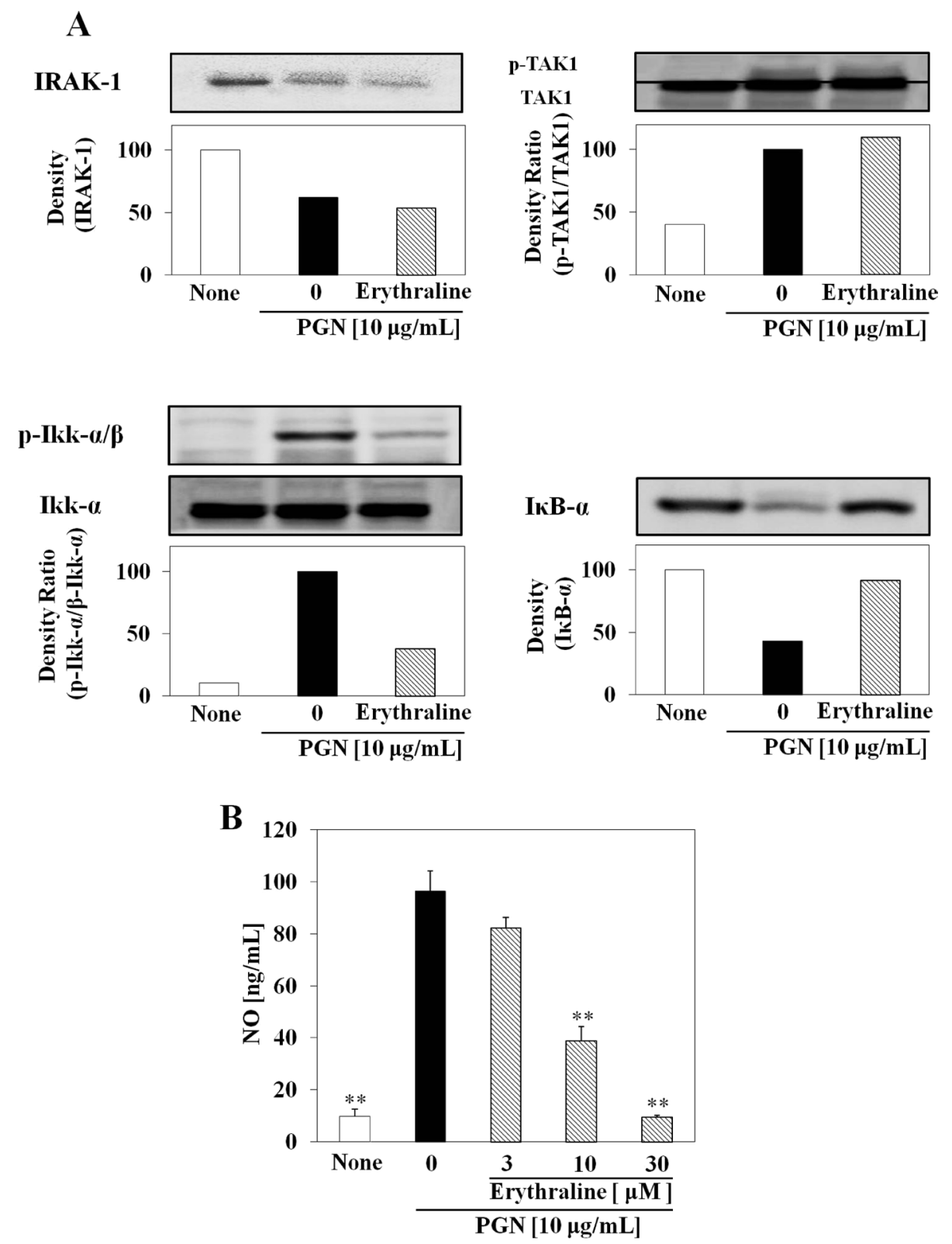

Fig. 5. Effects of Erythraline on PGN-Activated NO Production and TLR Signaling Molecules in RAW264.7 Cells

RAW264.7 cells $\left(2 \times 10^{6}\right.$ cells) were pre-treated at $37^{\circ} \mathrm{C}$ for $3 \mathrm{~h}$ with $30 \mu \mathrm{m}$ of erythraline before PGN $(10 \mu \mathrm{g} / \mathrm{mL})$ was added, and the cells were incubated for $10 \mathrm{~min}$ (TAK1), $20 \mathrm{~min}$ (IRAK-1 and Ikk- $\alpha$ ), or $30 \mathrm{~min}(\mathrm{I} \kappa \mathrm{B}-\alpha)$. After incubation, each of the signal proteins and their phosphorylation or degradation forms were determined by Western blot analysis (A). The density of IRAK- 1 and I $\kappa$ B- $\alpha$ protein and the relative density ratios of phosphorylated each signal proteins (TAK1 and Ikk- $\alpha$ ) to total each signal proteins are shown as histograms. The density ratio of PGN control is set to 100. Results shown are representatives of three independent experiments. RAW264.7 cells $\left(1 \times 10^{5}\right.$ cells $)$ were pre-treated at $37^{\circ} \mathrm{C}$ for $3 \mathrm{~h}$ with the indicated concentrations of erythraline before PGN $(10 \mu \mathrm{g} / \mathrm{mL})$ was added, and cells were incubated for $20 \mathrm{~h}$ (B). NO concentrations in the medium were measured by Griess reaction. Results shown are representatives of three independent experiments. Statistical significance; ** $p<0.01 v s$. corresponding PGN control.

(Fig. 1B). We found that erythraline did, however, inhibit not only LPS-induced NO production but also iNOS expression in RAW264.7 cells at 3,10 , and $30 \mu \mathrm{M}$ in a concentration-dependent manner (Fig. 2). It has been reported that the induction of NO production stimulated by LPS operates via TLR4 signaling pathway in inflammatory cells. ${ }^{18)}$ As a result, we proposed that anti-inflammatory effect of erythraline may operate in TLR-dependent manner and that the molecular target of erythraline is within the TLR signaling pathway. Therefore, we designed an experiment to investigate the effect of erythraline on TLR signaling.

Next, we investigated the effect of erythraline on nuclear translocation of $\mathrm{NF}-\kappa \mathrm{B}$. NF- $\kappa \mathrm{B}$ is transcription factor that activates the expression of many genes involved in the inflammatory response, including TNF- $\alpha$, iNOS, and IL- $1 .{ }^{19)}$ Our result showed that erythraline inhibited the nuclear translocation of NF- $\kappa$ B (Fig. 3), which is likely the mechanism for the effect of erythraline on expression of iNOS. NF- $\kappa \mathrm{B}$ is normally present in the cytosol in an inactive state complexed with $\mathrm{I} \kappa \mathrm{B}$. Its activation occurs via the phosphorylation of $\mathrm{I} \kappa \mathrm{B}-\alpha$ followed by its proteasomal degradation, which results in the nuclear translocation of NF- $\kappa \mathrm{B}$. Our results also showed that erythraline inhibited the degradation of $\mathrm{I} \kappa \mathrm{B}-\alpha$ (Fig. 4).

The phosphorylation of Ikk is required for the degradation of I $\kappa \mathrm{B}-\alpha$ by TLR ligands. In this study, erythraline inhibited the phosphorylation of Ikk (Fig. 4). This result suggested that 
the target molecule of erythraline was Ikk or its upstream signaling components. The component upstream of Ikk in the TLR signaling pathway is TAK1. Therefore, we examined the effect of erythraline on the phosphorylation of TAK1. In this study, the phosphorylation of TAK1 was evaluted by mobility shift. ${ }^{20)}$ Our results showed that erythraline did not inhibit the phosphorylation of TAK1 (Fig. 4). Signal components, such as TRAF6 and IRAKs, exist upstream of TAK1 in the TLR signaling pathway. IRAKs that have been identified, such as IRAK-1, ${ }^{21)}$ IRAK-2, ${ }^{22)}$ IRAK-4, ${ }^{23)}$ and IRAK-M, ${ }^{24)}$ are important mediators in MyD88-dependent pathway of TLR signaling, in particular IRAK-4 and IRAK-1, since they possess intrinsic serine/threonine kinase activity. In addition, it has been reported that IRAK-1 is autophosphorylated and degraded after phosphorylation by IRAK-4. ${ }^{25}$ ) Our study showed that erythraline did not inhibit LPS-induced IRAK-1 degradation (Fig. 4). This result suggests that erythraline inhibited the signal downstream from TAK1 in the TLR signaling pathway.

Our results suggested that erythraline inhibited the phosphorylation of Ikk or TAK1 kinase activity. In order to clarify the molecular target of erythraline, we looked at the effect of erythraline on MAPKs. It has been reported that MAPKs, such as JNK and p38MAPK, are phosphorylated by activated TAK1 in the TLR signaling pathway. ${ }^{26)}$ Our study showed that erythraline inhibited LPS-induced phosphorylation of JNK and p38MAPK (Fig. 4). These results suggested that erythraline is able to show its anti-inflammatory effect through the suppression of TAK1 kinase activity. In addition, we examined the effect of erythraline on PGN, a ligand of TLR2-induced NO production and TLR signaling. Our results showed that erythraline inhibited NO production, degradation of I $\kappa \mathrm{B}-\alpha$ and phosphorylation of Ikk (Fig. 5). Moreover, the phosphorylation of TAK1 and the degradation of IRAK-1 were not inhibited (Fig. 5). The inhibitory pattern of erythraline on TLR signaling molecules stimulated by PGN was similar to that during stimulated by LPS.

These findings suggest that TAK1 is one of the target molecule of erythraline likely involved in its anti-inflammatory effect. TAK 1 is a mitogen-activated protein kinase kinase kinase that can be activated not only by TLR ligands but also by IL-1. ${ }^{27)}$ It is possibile that TAK1 has a role in various inflammatory reactions. Therefore, erythraline contained in Erythrina crista-galli may show the effect on inflammatory diseases, such as rheumatism and hepatitis, through inhibition of TAK1.

\section{REFERENCES}

1) Hashimoto G. Illustrated Cyclopedia of Brazilian Medicinal Plants. ABOC-SHA, Kamakura, pp. 678-679 (1996)

2) Ozawa M, Kawamata S, Etoh T, Hayashi M, Komiyama K, Kishida A, Kuroda C, Ohsaki A. Structures of new Erythrinan alkaloids and nitric oxide production inhibitors from Erythrina crista-galli. Chem. Pharm. Bull., 58, 1119-1122 (2010).

3) Posadas I, Terencio MC, Guillén I, Ferrándiz ML, Coloma J, Payá M, Alcaraz MJ. Co-regulation between cyclo-oxygenase-2 and inducible nitric oxide synthase expression in the time-course of murine inflammation. Naunyn Schmiedebergs Arch. Pharmacol., 361, 98-106 (2000).

4) Moncada S, Higgs A, Furchgott R. International union of pharmacology nomenclature in nitric oxide research. Pharmacol. Rev., 49, 137-142 (1997)

5) Moncada S, Palmer RM, Higgs EA. Nitric oxide: physiology, pathophysiology, and pharmacology. Pharmacol. Rev., 43, 109-142 (1991).

6) Kröncke KD, Fehsel K, Kolb-Bachofen V. Inducible nitric oxide synthase in human diseases. Clin. Exp. Immunol., 113, 147-156 (1998).

7) Medzhitov R, Preston-Hurlburt P, Janeway CA Jr. A human homologue of the Drosophila Toll protein signals activation of adaptive immunity. Nature, 388, 394-397 (1997).

8) Brown KL, Cosseau C, Gardy JL, Hancock RE. Complexities of targeting innate immunity to treat infection. Trends Immunol., 28, 260-266 (2007).

9) Roach JC, Glusman G, Rowen L, Kaur A, Purcell MK, Smith KD, Hood LE, Aderem A. The evolution of vertebrate Toll-like receptors. Proc. Natl. Acad. Sci. U.S.A., 102, 9577-9582 (2005).

10) Takeuchi O, Hoshino K, Kawai T, Sanjo H, Takada H, Ogawa T, Takeda K, Akira S. Differential roles of TLR2 and TLR4 in recognition of Gram-negative and Gram-positive bacterial cell wall components. Immunity, 11, 443-451 (1999).

11) Hoshino K, Takeuchi O, Kawai T, Sanjo H, Ogawa T, Takeda $Y$, Takeda K, Akira S. Cutting edge: Toll-like receptor 4 (TLR4)-deficient mice are hyporesponsive to lipopolysaccharide: evidence for TLR4 as the Lps gene product. J. Immunol., 162, 3749-3752 (1999).

12) Hayashi F, Smith KD, Ozinsky A, Hawn TR, Yi EC, Goodlett DR, Eng JK, Akira S, Underhill DM, Aderem A. The innate immune response to bacterial flagellin is mediated by Toll-like receptor 5 . Nature, 410, 1099-1103 (2001).

13) Diebold SS, Kaisho T, Hemmi H, Akira S, Reis e Sousa C. Innate antiviral responses by means of TLR7-mediated recognition of single-stranded RNA. Science, 303, 1529-1531 (2004).

14) Heil F, Hemmi H, Hochrein H, Ampenberger F, Kirschning $C$, Akira S, Lipford G, Wagner H, Bauer S. Species-specific recognition of single-stranded RNA via Toll-like receptor 7 and 8. Science, 303, 1526-1529 (2004)

15) Akira S. Toll-like receptor signaling. J. Biol. Chem., 278, 3810538108 (2003).

16) Takeda K, Akira S. Toll receptors and pathogen resistance. Cell. Microbiol., 5, 143-153 (2003).

17) Green LC, Wagner DA, Glogowski J, Skipper PL, Wishnok JS, Tannenbaum SR. Analysis of nitrate, nitrite, and $[15 \mathrm{~N}]$ nitrate in biological fluids. Anal. Biochem., 126, 131-138 (1982).

18) Schröder NW, Opitz B, Lamping N, Michelsen KS, Zähringer U, Göbel UB, Schumann RR. Involvement of lipopolysaccharide binding protein, $\mathrm{CD} 14$, and Toll-like receptors in the initiation of innate immune responses by Treponema glycolipids. J. Immunol., 165, 2683-2693 (2000).

19) Baeuerle PA, Baltimore DNF. NF- $\kappa$ B: ten years after. Cell, 87, 13-20 (1996).

20) Fraczek J, Kim TW, Xiao H, Yao J, Wen Q, Li Y, Casanova JL, Pryjma J, Li X. The kinase activity of IL-1 receptor-associated kinase 4 is required for interleukin-1 receptor/Toll-like receptorinduced TAK1-dependent NFkappaB activation. J. Biol. Chem., 283, 31697-31705 (2008).

21) Cao Z, Henzel WJ, Gao X. IRAK: a kinase associated with the interleukin-1 receptor. Science, 271, 1128-1131 (1996).

22) Muzio M, Ni J, Feng P, Dixit VM. IRAK (Pelle) family member IRAK-2 and MyD88 as proximal mediators of IL-1 signaling. Science, 278, 1612-1615 (1997).

23) Li S, Strelow A, Fontana EJ, Wesche H. IRAK-4: a novel member of the IRAK family with the properties of an IRAK-kinase. Proc. Natl. Acad. Sci. U.S.A., 99, 5567-5572 (2002).

24) Wesche H, Gao X, Li X, Kirschning CJ, Stark GR, Cao Z. IRAK$\mathrm{M}$ is a novel member of the Pelle/interleukin-1 receptor-associated kinase (IRAK) family. J. Biol. Chem., 274, 19403-19410 (1999).

25) Yamin TT, Miller DK. The interleukin-1 receptor-associated kinase is degraded by proteasomes following its phosphorylation. J. Biol. Chem., 272, 21540-21547 (1997). 
26) Sato S, Sanjo H, Takeda K, Ninomiya-Tsuji J, Yamamoto M, Kawai T, Matsumoto K, Takeuchi O, Akira S. Essential function for the kinase TAK1 in innate and adaptive immune responses. Nat. Immunol., 6, 1087-1095 (2005).
27) Ninomiya-Tsuji J, Kishimoto K, Hiyama A, Inoue J, Cao Z, Matsumoto K. The kinase TAK1 can activate the NIK-I $\kappa$ B as well as the MAP kinase cascade in the IL-1 signalling pathway. Nature, $\mathbf{3 9 8}$, 252-256 (1999). 